\title{
Fc and C3 Receptors Induced by Herpes Simplex Virus on Cultured Human Endothelial Cells
}

\author{
Douglas B. Cines, Alan P. Lyss, and Mahin Bina, Hematology-Oncology Section, \\ Richard Corkey and Nicholas A. Kefalides, Connective Tissue \\ Research Institute, Harvey M. Friedman, Infectious Disease Section, \\ Department of Medicine, University of Pennsylvania, Philadelphia, \\ Pennsylvania 19104
}

\begin{abstract}
A B S TRACT The mechanism by which immune complexes deposit in vascular tissue is uncertain. Several human viruses, including herpes simplex virus, have recently been demonstrated to replicate in human endothelial cells. Such viruses may injure vascular tissue and could play a role in the pathogenesis of immune complex deposition. Therefore, we studied the expression of receptors for immune complexes containing IgG and C3 on endothelial cells after infection with herpes simplex virus type $I$.
\end{abstract}

Human umbilical vein endothelial cells were incubated with ${ }^{51} \mathrm{Cr}$-labeled sheep erythrocytes sensitized with IgG, IgM, or IgM plus complement. Preferential binding of IgG or complement-coated erythrocytes to uninfected endothelial monolayers was not observed. In contrast, significant binding of erythrocytes coated with IgG or IgM plus complement was observed after viral infection. Phase-contrast and scanning electron microscopy demonstrated erythrocyte adherence around the infected endothelial cells in a rosette pattern. Binding of IgG-coated erythrocytes was fully inhibited by Fc $(0.31 \mathrm{mg} / \mathrm{ml})$ but not $\mathrm{Fab}^{\prime}$ fragments of nonimmune IgG. Binding of complement-coated cells was unaffected by the presence of $\operatorname{IgG}(1 \mathrm{mg} / \mathrm{ml})$. With purified individual components, binding of complement-coated erythrocytes depended on the presence and was proportional to the concentration of $\mathrm{C} 3$. Binding of IgG-or C3-coated cells was detected beginning $4 \mathrm{~h}$ after infection.

These studies indicate that herpes simplex virus type I infection can induce IgG and C3 receptors on human endothelial cells. These receptors may promote the

This work was presented, in part, at the annual meeting of the American Heart Association, Miami, Florida, November 1980.

Received for publication 14 February 1981 and in revised form 3 September 1981. deposition of immune complexes in vascular tissue after certain viral infections.

\section{INTRODUCTION}

Immune vascular injury is presumed to occur in a variety of human diseases. Circulating immune complexes have been identified in several of these disorders, and their localization in the vessel wall is one process thought to initiate vasculitis (1). However, the mechanism by which such complexes localize in vascular tissue is uncertain (1). Recent studies suggest that the localization of immune complexes in the kidney may depend upon the presence of specific tissue binding sites for immune complexes containing IgG and complement (2). Similar binding sites have not been observed on endothelial cells. Indeed, cells obtained from bovine pulmonary artery have been shown to lack Fc (IgG) and C3 receptors (3).

Viral antigens have been detected in vessel walls in several forms of vasculitis $(4,5)$. For example, immune complex deposition in the cutaneous microvasculature after herpes simplex virus (HSV) ${ }^{1}$ infection has been implicated in the development of erythema multiforme in some patients (6). In addition, $\mathrm{Fc}$ receptors can be demonstrated on cultured fibroblasts and other cell lines after infection with several herpes-family viruses (7-9). Therefore, we questioned whether viral infection of human endothelial cells with herpes simplex virus type I (HSV I) would induce a receptor for Fc and/or C3 on the endothelial cell surface.

\section{METHODS}

Endothelial cells were harvested from human umbilical cord veins by collagenase digestion according to a modification

\footnotetext{
${ }^{1}$ Abbreviation used in this paper: HSV, herpes simplex virus.
} 
of the method of Jaffe et al. (10), as described (10-12). The cells were grown in Eagle's minimum essential medium or medium 199 supplemented with $20 \%$ heat-inactivated fetal calf serum. Confluent monolayers were prepared in 24-well microtiter plates (Costar Corp., Cambridge, Mass.) and contained $\sim 1.5-2.0 \times 10^{5}$ endothelial cells/well. The cells were identified as endothelial by their characteristic appearance under light miscroscopy, by the presence of endothelial-specific Weible-Palade bodies demonstrated by transmission electron microscopy, and by indirect immunofluorescence demonstration of factor VIII antigen (13). Cells from 3- to 13-d-old primary cultures were used in these studies with similar results. One-half of the wells were infected with HSV I at a multiplicity of infection of $0.5-1.0\left(10^{5}\right.$ Tissue Culture Infectious Doses Dolwell . The remaining half of the wells were sham infected to serve as controls. After a 1-h adsorption at $37^{\circ} \mathrm{C}$, the monolayers were washed and refed with $1 \mathrm{ml}$ of medium. The cells were then incubated for $24 \mathrm{~h}$ at $37^{\circ} \mathrm{C}$, examined for cytopathic effect by phase-contrast microscopy, and used for the studies described below. Monolayers were also prepared from human mononuclear cells separated by Hypaque-Ficoll density centrifugation by established methods (14). These cells were utilized as positive controls for the binding of antibody or complement-coated erythrocytes.

We used ultraviolet light-irradiated virus as a control for the effect of adsorption of viral membrane glycoproteins to the endothelial cell surface. HSV was exposed to ultraviolet light irradiation as previously described (15). A 15-min exposure of the cell-free HSV inactivated the virus, resulting in a decline in titer from $10^{6}$ plaque-forming units $/ \mathrm{ml}$ to no infectious virus. Endothelial cells were interacted with the ultraviolet light-irradiated virus for 24-72 $\mathrm{h}$ in an identical manner to the nonirradiated virus and studied for the development of IgG and complement receptors.

The ability of uninfected or virally infected endothelial cells to bind immunoglobulin- or complement-coated particles was studied. Fresh sheep erythrocytes (E) were radiolabeled with ${ }^{51} \mathrm{Cr}\left(\mathrm{Na}_{2} \mathrm{CrO}_{4}\right.$, New England Nuclear, Cambridge, Mass.) and sensitized with subagglutinating doses of the 7S (IgG) or the 19S (IgM) fraction of rabbit anti-sheep erythrocyte serum (Cordis Laboratories Inc., Miami, Fla.) to coat them with IgG (EAIgG) and IgM (EAIgM), respectively. Guinea pig $\mathrm{Cl}$ and $\mathrm{C} 2$ were prepared by established methods $(16,17)$; human $\mathrm{C} 4$ and $\mathrm{C} 3$ were purchased from Cordis Laboratories. Complement-coated erythrocytes were prepared with either EAIgM incubated with sublytic concentrations (1:40) of normal human serum for $15 \mathrm{~min}$ at $37^{\circ} \mathrm{C}$ (EAIgMC) or EAIgM incubated with the stepwise addition of purified complement components to produce the complement intermediates EACl, EACl4, and EAC1423. To prepare EAC1423, a concentration of 100 sites/cell of purified C4 was used. In select experiments, EAC14 cells were prepared at $\mathrm{C} 4$ concentrations of 1,000 or 3,000 sites/ cell. The presence and amount of human C3 on these erythrocytes was established by the specific adsorption of ${ }^{125} \mathrm{I}$ antiC3 as previously described (18). The complement intermediates EAC1423 and the heavily sensitized EAC14 cells used in these experiments were demonstrated to be immune adherence positive (19). The labeled erythrocyte indicator cells

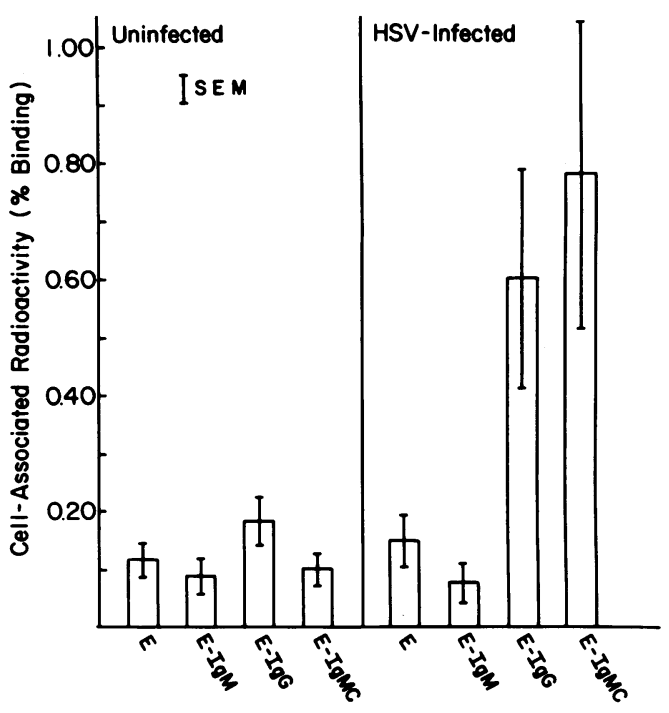

FIGURE 1 Binding of antibody or complement-coated erythrocytes to uninfected or HSV I-infected human endothelial cells. ${ }^{51} \mathrm{Cr}$-labeled indicator cells were incubated with the endothelial monolayer, and the percent binding was determined. The results $\pm S E M$ of nine experiments are shown.

were adjusted to a concentration of $1 \times 10^{8}$ cells $/ \mathrm{ml}$ in Eagle's minimum essential medium. An aliquot from each suspension $(0.2 \mathrm{ml})$ was added to the uninfected or HSVinfected endothelial cell monolayers and incubated for $2 \mathrm{~h}$ at $37^{\circ} \mathrm{C}$. The wells were washed vigorously three times with $1 \mathrm{ml}$ of Hanks' balanced salt solution (Microbiological Associates, Walkersville, Md.). The monolayers were then viewed by phase-contrast or scanning electron microscopy to assess the distribution of bound erythrocytes. At least four erythrocytes adherent to the surface of an endothelial cell was required for the identification of a "rosette." After microscopic evaluation, the adherent erythrocytes were lysed with $2 \mathrm{ml}$ of distilled water, and the supernatant fluids were counted for gamma emission (Gamma 8000, Beckman Instruments, Inc., Irvine, Calif.).

Human IgG free of anti-HSV I antibody was prepared by anion exchange and gel filtration chromatography as previously described (18). The Fc and Fab' fragments of IgG were prepared by papain digestion and separated on carboxymethyl cellulose by established methods (20).

Scanning electron microscopy was performed after glutaraldehyde fixation and critical endpoint drying with a SEM 500 scanner (Philips Electronic Instruments, Inc., Mahwah, N. J.) as previously described (21).

\section{RESULTS}

Less than $0.2 \%$ of unsensitized, antibody-coated, or complement-coated erythrocytes bound to uninfected endothelial cells (Fig. 1). Similarly, there was little

FIgure 2 (a) Phase-contrast micrograph of the HSV I-infected endothelial monolayer after incubation with C3-coated sheep erythrocytes prepared with purified individual complement components (EAIgMC1423). (b) Scanning electron micrograph of the HSV I-infected endothelial monolayer after incubation with IgM and complement-coated sheep erythrocytes. $a$, $\times 200 ; b, \times 2,500$. 

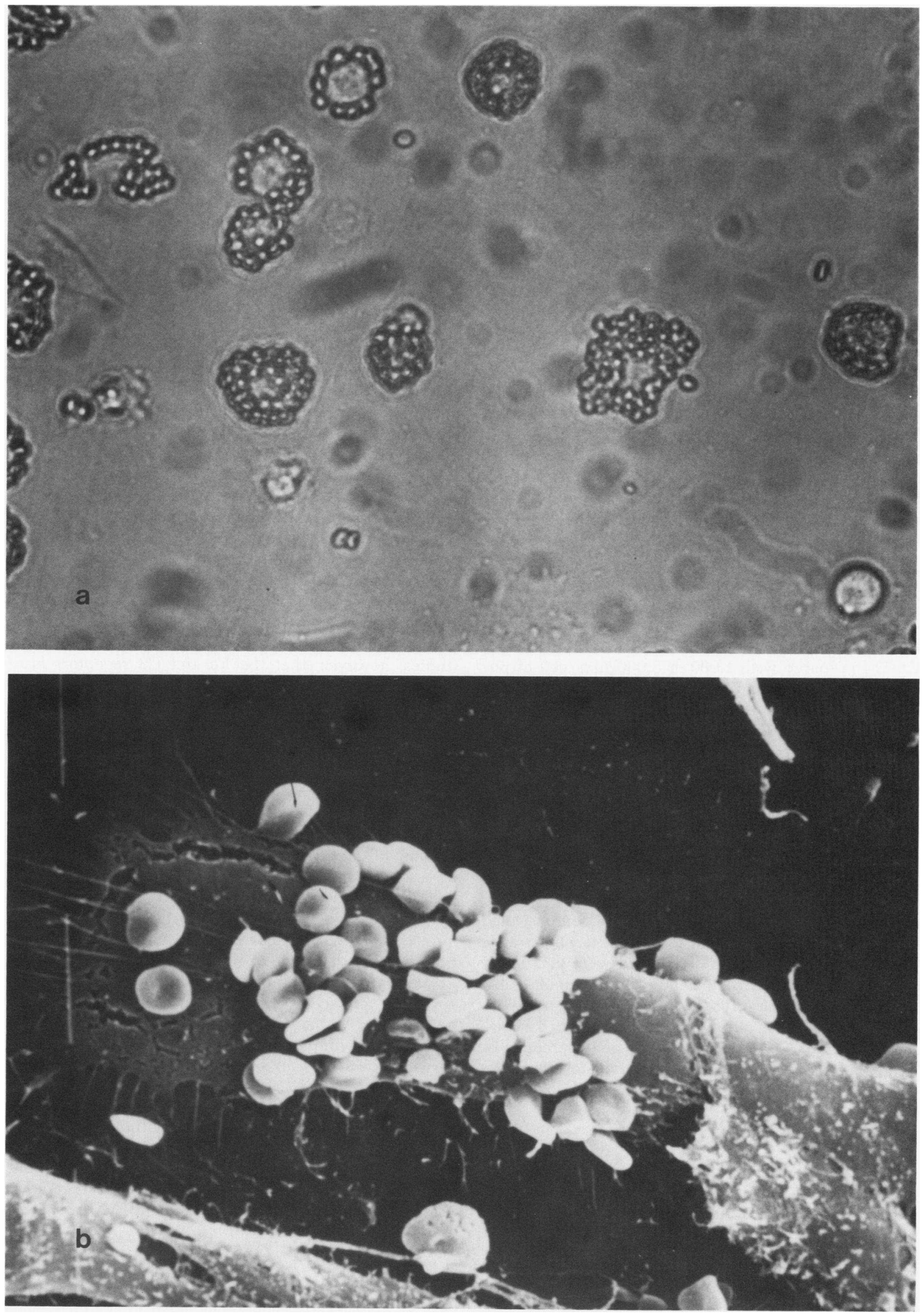
adherence of sheep erythrocytes or EAIgM to HSVinfected endothelium as observed visually or as determined by the amount of bound radioactivity (Fig. 1). In contrast, significant binding of EAIgG and EAIgMC to the endothelium occurred after HSV infection (paired Student's $t$ test: $P<0.05$, Fig. 1). Virtually all bound erythrocytes were located around the periphery of individual endothelial cells in a rosette pattern, and many endothelial cells bound greater than twenty erythrocytes per cell (Fig. $2 a$ ). Cell-to-cell contact between the antibody- and complement-coated erythrocytes and the $\mathrm{HSV}$-infected endothelial cells was further evident on scanning electron microscopy (Fig. 2 b). Over $80 \%$ of the infected endothelial cells formed rosettes with the IgG or complement-coated erythrocytes. Preincubation of the endothelial monolayers with purified IgG $(\geq 0.17 \mathrm{mg} / \mathrm{ml})$ or with $\mathrm{Fc}$ fragments $\left(\geq 0.31 \mathrm{mg} / \mathrm{ml}\right.$ ) but not with their $\mathrm{Fab}^{\prime}$ fragments $(\geq 0.29 \mathrm{mg} / \mathrm{ml})$ or with purified human albumin (1 $\mathrm{mg} / \mathrm{ml}$ ) completely inhibited the binding of EAIgG. In contrast, the binding of EAIgMC was not inhibited by preincubating the monolayer with purified IgG or albumin $(1 \mathrm{mg} / \mathrm{ml})$.

C3 mediated the binding of the complement-coated erythrocytes (EAIgMC) to HSV-infected endothelium. Uninfected and HSV-infected endothelial cells bound similar amounts $(<0.2 \%)$ of sheep erythrocytes, EAIgM, and the complement intermediate EACl. Similarly, EACl4 prepared with 1,000 or 3,000 sites/cell of purified $\mathrm{C} 4$ did not form rosettes with the virally infected endothelial monolayers. Enhanced binding $(>0.8 \%)$ to virally infected cells occurred only after sensitization with purified human C3. In addition, the binding of EACl423 was proportional to the concentration of $\mathrm{C} 3$ (10-500 hemolytic U/cell) used to sensitize the cells.

The time-course for the development of these receptors was studied. Endothelial monolayers were infected with HSV I at multiplicity of infection of 1.0, incubated for $1-24 \mathrm{~h}$ at $37^{\circ} \mathrm{C}$, washed, and interacted with labeled erythrocyte indicator cells. Receptors for EAIgMC1423 and EAIgG could not be demonstrated $30 \mathrm{~min}, 1 \mathrm{~h}$, or $2 \mathrm{~h}$ after infection. Both receptors were demonstrable $4 \mathrm{~h}$ after infection and were maximally expressed by $18 \mathrm{~h}$. These receptors were demonstrable before a cytopathic effect was evident by phase-contrast microscopy. In simultaneously performed experiments neither Fc nor C3 receptor activity could be detected with endothelial cells exposed to ultraviolet light-inactivated virus for periods of 24-72 h.

\section{DISCUSSION}

Disorders attributed to the deposition of immune complexes in vessel walls show a wide divergence of clinical expression and often follow an episodic clinical course. Immune complexes may circulate without producing clinically detectable systemic vascular injury (1). In part, this may be attributed to the limited capacity of normal endothelium to recognize and bind such complexes (Fig. 1) (3). In addition, injury due to immune complex deposition may be anatomically restricted within the vascular system of a single organ or to certain types of blood vessels. Several processes may influence immune complex deposition, including alteration of the composition or titer of the complexes themselves, saturation of the reticuloendothelial system, and the release of vasoactive amines from platelets and other cells by these complexes $(1,22,23)$. Previous work has also demonstrated antigen localization within host tissue, and in situ antibody production may also be important in determining the site of immune injury $(24,25)$. The induction of receptors for IgG and C3 on endothelial cells after viral infection may also influence immune complex deposition.

The results of this study indicate that within $4 \mathrm{~h}$ of infection, HSV I induces the expression of Fc and C3 receptors on human endothelial cells. Recently, the Fc receptor induced by HSV on Hep 2 and Vera cells has been characterized and demonstrated to be a viral glycoprotein (26). The presence of a C3 receptor on any cell surface after HSV infection has not previously been described. Whether this is also a viral glycoprotein remains to be determined. It is clear from our studies, however, that the $\mathrm{Fc}$ and $\mathrm{C} 3$ receptors are distinct. Firstly, purified IgG completely inhibited binding of IgG-coated cells to the Fc receptor without diminishing the binding of the IgM and complementcoated cells. Secondly, with purified individual complement components, binding of IgM-coated cells required the presence of purified C3. The C3-coated cells used in these experiments were demonstrated to be immune adherence positive (19). In addition, the binding of the C3-coated cells occurred in the absence of a source of $\mathrm{C} 3 \mathrm{~b}$ inactivator or $\beta 1 \mathrm{H}$. Therefore, it is likely that this binding is mediated, at least in part, by the presence of $\mathrm{C} 3 \mathrm{~b}$ on the erythrocyte.

In contrast to cells coated with human $\mathrm{C} 3$, we did not observe adherence to infected endothelial cells of erythrocytes heavily sensitized with human $\mathrm{C4}$. Therefore, the C3 receptor induced on human endothelial cells appears to have a limited capacity to recognize cells coated with $\mathrm{C} 4 \mathrm{~b}$. Rosetting might have been observed, however, had even higher concentrations of C4 been employed (19).

Our data suggest that the expression of $\mathrm{Fc}$ and $\mathrm{C} 3$ receptors on the virally infected endothelial cells does not simply reflect adsorption of viral glycoprotein to the cell surface. Firstly, at the multiplicity of infection employed throughout these studies, both receptors were first detected $4 \mathrm{~h}$ after exposure to the virus. Sec- 
ondly, we used ultraviolet light-inactivated virus, which is capable of adsorption to the cell but not complete viral replication (15). Inactivated virus did not induce $\mathrm{Fc}$ or $\mathrm{C} 3$ receptors on endothelial cells over a 24-72-h period, by which time cells infected with live virus showed intense rosetting with IgG or C3-coated erythrocytes.

In separate studies performed in our laboratory, HSV has been noted to produce a persistent infection of cultured endothelial cells (H. M. Friedman, unpublished observation). This virus also produces persistent or latent infection of sensory ganglia cells in vivo after infection at the end organs innervated by the ganglia (27-29). If similar events occur after endothelial infection in vivo, chronic or remitting vessel wall infection may ensue. We have shown in vitro that endothelial cells derived from human umbilical vein, bovine thoracic aorta (30), bovine pulmonary artery and vena cava (H. M. Friedman, unpublished observations) show similar susceptibility to HSV I infection. Therefore, the expression of IgG and C3 receptors that we observed in this study may occur after HSV I infection of endothelial cells derived from a number of vascular sites. The induction of these receptors by HSV I may promote binding of immune complexes, initiate activation of complement, and lead to vasculitis or other forms of chronic vessel wall injury.

\section{ACKNOWLEDGMENTS}

We thank Jayneann Wolfe, Roxanne Breenes, Krystyna Knight, and Rena Finko for their technical assistance; Susan Widirstky and Dr. Vivian Nachmias for the scanning electron micrographs; and Patricia Lafferty and Diane Shinn for their help in preparing this manuscript.

This work was supported by grants AM-20533, HL-18827, HL-24914, HL-23750, and AHA 79-1074 from the National Institutes of Health and the American Heart Association.

\section{REFERENCES}

1. Cochrane, C. G. 1971. Mechanisms involved in the deposition of immune complexes in tissue. J. Exp. Med. 134(Suppl.): 75-89.

2. Shin, M. L., M. C. Gelfand, R. B. Nagle, J. R. Carlo, I. Green, and M. M. Frank. 1977. Localization of receptors for activated complement on visceral epithelial cells of the human renal glomerulus. J. Immunol. 118: 869-873.

3. Ryan, U. S., D. R. Schultz, P. J. Del Vecchio, and J. W. Ryan. 1980. Endothelial cells of bovine pulmonary artery lack receptors for $\mathrm{C} 3 \mathrm{~b}$ and for the $\mathrm{Fc}$ portion of immunoglobulin G. Science (Wash. D. C.). 208: 748749.

4. Gocke, D. J., K. Hsu, C. Morgan, S. Bombardier, M. Lockshin, and C. L. Christian. 1971. Vasculitis in association with Australia antigen. J. Exp. Med. 134(Suppl.): 330-336.

5. Gower, R. G., W. F. Sausker, P. F. Kohler, G. E. Thorne, and R. M. McIntosh. 1978. Small vessel vasculitis caused by hepatitis B virus immune complexes. J. Allergy Clin. Immunol. 62: 222-228.
6. Kazmicrowski, J. A., and K. D. Wupper. 1978. Erythema multiforme: immune complex vasculitis of the superficial cutaneous microvasculature. J. Invest. Dermatol. 71: 366-369.

7. Westmoreland, D., and J. F. Watkins. 1974. The IgG receptor induced by herpes simplex virus: studies using radioiodinated IgG. J. Gen. Virol. 24: 167-178.

8. Sakuma, S., T. Furokawa, and S. A. Plotkin. 1977. The characterization of the IgG receptor induced by human cytomegalovirus. Proc. Soc. Exp. Biol. Med. 155: 168172.

9. Ogata, M., and S. Shigeta. 1979. Appearance of immunoglobulin $G$ Fc receptor in cultured human cells infected with varicella-zoster virus. Infect. Immun. 26: 770-774.

10. Jaffe, E. A., A. L. Nachman, C. G. Becker, and C. R. Minick. 1973. Culture of human endothelial cells derived from umbilical veins. Identification by morphologic and immunologic criteria. J. Clin. Invest. 52: 27452756.

11. Gimbrone, M. A., R. S. Cotran, and J. Folkman. 1974. Human vascular endothelial cells in culture. J. Cell Biol. 60: 673-684.

12. MacGregor, R. R., H. M. Friedman, E. J. Macarak, and N. A. Kefalides. 1980. Virus infection of endothelial cells increases granulocyte adherence. J. Clin. Invest. 65: 1469-1477.

13. Jaffe, E. H., L. W. Hoyer, and R. L. Nachman. 1973. Synthesis of anti-hemophiliac factor antigen by cultured human endothelial cells. J. Clin. Invest. 52: 2757-2764.

14. Schreiber, A. D., J. Parsons, P. McDermott, and R. A. Cooper. 1975. Effect of corticosteroids on the human monocyte IgG and complement receptors. J. Clin. Invest. 56: 1189-1197.

15. Lytle, C. D. 1971. Host-cell reactivation in mammalian cells. I. Survival of ultraviolet-irradiated herpes virus in different cell lines. Int. J. Radiat. Biol. Relat. Stud. Phys. Chem. Med. 19: 329-337.

16. Ruddy, S., and K. F. Austen. 1967. A stoichiometric assay for the fourth component of complement in whole human serum using $\mathrm{EAC}^{\prime} 1 \mathrm{a}^{\mathrm{gp}}$ and functionally pure human second component. J. Immunol. 99: 1162-1172.

17. Schreiber, A. D., and K. F. Austen. 1974. Hageman factor-independent fibrinolytic pathway. Clin. Exp. Immunol. 17: 587-600.

18. Cines, D. B., and A. D. Schreiber. 1979. Immune thrombocytopenia: use of a Coombs' antiglobulin test to detect IgG and C3 on platelets. New Engl. J. Med. 300: 106110.

19. Cooper, N. R. 1969. Immune adherence by the fourth component of complement. Science (Wash. D. C.). 165: 396-398.

20. Porter, R. R. 1959. The hydrolysis of rabbit $\gamma$-globulin and antibodies with crystalline papain. Biochem. J. 73: 119-126.

21. Nachmias, V. T., J. S. Sullender, and J. F. Fallon. 1979. Effects of local anaesthetics on human platelets: filopodial suppression and endogenous proteolysis. Blood. 53: 63-72.

22. Finbloom, D. S., D. B. Magilavy, J. B. Harford, A. Rifai, and P. L. Plotz. 1981. Influence of antigen on immune complex behavior in mice. J. Clin. Invest. 68: 214-224.

23. Gallo, G. R., T. Caulin-Glaser, and M. E. Lamm. 1981. Charge of circulating immune complexes as a factor in glomerular basement membrane localization in mice. $J$. Clin. Invest. 67: 1305-1313.

24. Golbus, S. M., and C. B. Wilson. 1979. Experimental 
glomerulonephritis induced by in situ formation of immune complexes in glomerular capillary wall. Kidney Int. 16: 148-157.

25. Cousen, W. G., and D. J. Salant. 1980. In situ immune complex formation and glomerular injury. Kidney Int. 17: $1-13$.

26. Para, M. F., R. B. Baucke, and P. G. Spear. 1980. Immunoglobulin $G(\mathbf{F c})$-binding receptors on viruses of herpes simplex virus type I and transfer of these receptors to the cell surface by infection. J. Virol. 34: 512520.

27. Baringer, J. R., and R. P. Swoveland. 1973. Recovery of herpes simplex virus from human trigeminal ganglions. New Engl. J. Med. 288: 648-650.

28. Baringer, J. R. 1974. Recovery of herpes simplex virus from human sacral ganglions. New Engl. J. Med. 291: 828-830.

29. Warren, K. G., S. M. Brown, Z. Wroblewska, D. Gilden, H. Koprowski, and J. Subak-Sherpe. 1978. Isolation of latent herpes simplex virus from the superior cervical and vagus ganglions of human beings. New Engl. J. Med. 298: 1068-1069.

30. Friedman, H. M., E. J. Macarak, R. R. McGregor, J. Wolfe, and N. A. Kefalides. 1981. Virus infection of endothelial cells. J. Infect. Dis. 143: 266-273. 